\title{
NILAI EDUKATIF DALAM BUDAYA LOMBOK NYONGKOLAN
}

\author{
M. Chaerul Jamal Munawir \\ PPS, Universitas Negeri Yogyakarta \\ Email: jamalmunawir95@gmail.com
}

\begin{abstract}
Abstrak
Lombok secara kultural memiliki kultur perpaduan antara jawa, bali dan bugis. Suku sasak Lombok seperti suku-suku lainnya yang ada di dunia ini juga menjunjung tinggi nilai kultural budaya mereka, salah satu yang bisa kita lihat dan sering kita temui adalah tradisi "nyongkolan" yang memiliki pengetahuan lokal budaya lombok. Penelitian ini bertujuan untuk untuk menjadikan tradisi budaya nyongkolan sebagai bahan ajar di sekolah. Model pendekatan dalam peneletian ini mengarah ke etnografi deskriptif kualitatif. Realitas empiris diperoleh peneliti langsung ke lokasi penelitian, untuk mendapatkan gambaran tentang tentang budaya "nyongkolan" sesuai dengan tradisi mereka, dan gejala kehidupan sehari-hari Penelitian ini menggunakan metode penelitian kuantitatif deskriptif. Subjek penelitian adalah masyarakat Selebung Kecamatan Janapria. Pengumpulan data dilakukan melalui observasi, wawancara, dan dokumen. Analisis menurut Miles dan Huberman, yaitu (1). Reduksi data, (2) Penyajian data, (3) penarikan simpulan. Hasil penelitian Tradisi Merariq atau kawin lari Masyarakat Sasak memiliki banyak ritual atau tahapantahapan lain.
\end{abstract}

Kata kunci: nilai edukatif, Nyongkolan, bahan ajar, siswa

\section{EDUCATIONAL VALUE IN THE CULTURE OF LOMBOK NYONGKOLAN}

\begin{abstract}
Culturally, Lombok culture is a fusion between Java, Bali and Bugis cultures. Like other tribes in the world, Lombok Sasak tribes also uphold their cultural values. One of which we can see and often meet is the "nyongkolan" tradition, which contains a local cultural knowledge of Lombok culture. This study aims to make the cultural tradition of nyongkolan as teaching materials in schools. The approach model of this research leads to qualitative descriptive ethnography. An empirical reality obtained by the researchers directly to the location of the study, to get a picture of the culture of "nyongkolan" in accordance with the traditions, and the daily life symptoms. This study uses descriptive quantitative research methods. The subjects of the research were the Selebung community of Kecamatan Janapria. Data collection is conducted through observations, interviews, and documents. The data analysis is done according to Miles and Huberman's theory, namely (1) Data reduction, (2) Data presentation, (3) Drawing conclusions. The research results of the Merariq Tradition or elopement of the Sasak Society have many rituals or other stages.
\end{abstract}

Keywords: educational values, Nyongkolan, teaching materials, learners

\section{PENDAHULUAN}

Orang Sasak, Bugis, dan Arab mayoritas beragama Islam; orang Bali beragama Hindu; dan orang-orang Cina beragama Kristen. Setiap daerah mempunyai tradisi dan budaya yang unik, menjadikan Indonesia kaya akan budaya. Seperti halnya dalam merayakan pernikahan sepasang pengantin, seperti Nyongkolan 
merupakan tradisi yang berasal dari Pulau Lombok, Nusa Tenggara Barat. Nyongkolan adalah sebuah kegiatan adat yang menyertai rangkaian acara dalam prosesi perkawinan atau pernikahan pada suku sasak di Lombok Nusa Tenggara Barat, kegiatan ini berupa arakarakan, kedua mempelai dari rumah mempelai pria ke rumah mempelai wanita, dengan diiringi keluarga dan kerabat mempelai pria, memakai baju adat, serta rombongan musik yang bisa disebut gamelan atau kelompok penabuh rebana, atau disertai Gendang beleq. Dalam Pelaksanaannya rombongan dari mempelai pria mulai berjalan dari jarak $1-1 / 5 \mathrm{~km}$ dari rumah mempelai wanita.

Fenomena perkawinan ini dapat dikategorikan dalam tindakan tradisional karena sudah menjalankan perkawinan sesuai dengan adat dan tradisi daerahnya yang sudah ada sejak zaman dahulu. Bagi orang tua perempuan jika diminta anaknya secara terus terang, maka akan tersinggung karena anak gadisnya disamakan dengan benda atau barang lainnya. Hal ini menunjukkan bahwa tradisi yang dijalani oleh masyarakat suku Sasak merupakan sebuah komunikasi budaya yang melekat dalam tatanan sosial. Tradisi kawin culik yang dijalani oleh masyarakat suku Sasak khususnya di Lombok Tengah tidak menjadi suatu masalah melainkan menjadi tradisi yang unik. Tradisi tersebut sudah membudaya bagi masyarakat Sasak, hal itulah yang menjadi perbedaan dari tradisi dan adat istiadat di daerah-daerah lainnya dalam hal perkawinan.

Melakukan perkawinan dengan cara menculik terkesan menjadi sebuah bentuk pilihan dalam sikap yang menggunakan tradisi adat sebagai cara untuk mencapai tujuan. Jika, melakukan perkawinan dengan cara meminang sebagai bentuk izin dari keluarga perempuan terkadang cukup memberatkan dan membutuhkan modal serta kesiapan psikologis yang harus ditanggung oleh pria Sasak. Terkadang dalam lamaran terjadi penolakan oleh wali perempuan karena adanya perbedaan status sosial, dan syarat-syarat lainnya yang harus dipenuhi oleh pelamar yang terkadang bisa memberatkan bagi seorang pria. Maka, keputusan yang biasa diambil oleh pemuda pemudi Sasak adalah dengan melakukan kawin culik menjadi sebuah pilihan yang tepat bagi pasangan. Dalam adat perkawinan Sasak bila kedua pasangan telah melakukan kawin culik, maka penyelesaian masalah dalam proses perkawinan akan mempermudah mendapatkan persetujuan wali, serta menjadi keharusan bagi pihak wali perempuan untuk menyetujuinya. Jika tidak menyelesaikan persoalan perkawinan akan menjadi aib bagi keluarga yang dikesankan menyalahi adat.

Tujuan dari prosesi ini adalah untuk memperkenalkan pasangan mempelai tersebut ke masyarakat, terutama pada kalangan kerabat maupun masyarakat di mana mempelai perempuan tinggal, karena biasanya seluruh rangkaian acara pernikahan dilaksanakan di pihak mempelai laki-laki. Sebagian Pengiring dalam prosesi ini biasanya membawa beberapa benda seperti hasil kebun, sayuran maupun buah-buahan yang akan dibagikan pada kerabat dan tetangga mempelai perempuan nantinya. Untuk pengiring wanita biasanya berada di bagian depan rombongan, sedangkan pengiring pria berada di barisan belakang. Mereka mengenakan pakaian adat khas Lombok, menggunakan baju lambung dankain songket dari perut sampai bawah lutut dan berbagai aksesorisnya unuk perempuan dan baju berwarna hitam menggunakan sarung yang pemakaiannya dari perut sampai sekitar lutut yang memiliki warna hitam. Sedangkan aksesoris di kepala menggunakan kain warna hitam yang disusun dan dipasang menyerupai blangkon fungsinya sebagai ikat kepala untuk para laki-laki.

Budaya nyongkolan juga harus diapresiasi oleh masyarakat lombok karena banyak terdapat nilai edukatif pada budaya tersebut untuk di jadikan bahan ajar ke anak sekolah atau di dunia pendidikan untuk menjaga kelestarian budaya tersebut agar budaya peninggalan nenek moyang kita tradisi terdahulu tidak punah. Adapun cara mengantisipasinya dengan cara memperkenalkan budaya nyongkolan sebagai bahan ajar di sekolah lebih cendrung untuk mengkaji nilai edukatif yang terkadung 
pada budaya nyongkolan tersebut, adapun nilai edukatif yang bisa di peroleh dalam budaya nyongkolan bertanggung jawab, bersosialisasi, kekompakan, kebersamaan, menjalin hububungan silaturrahmi dan nilai gotong royong.

Nilai edukatif adalah nilai-nilai yang terdapat dalam masyarakat, mengajarkan tentang pendidikan kepada masyarakat (Noviyanti, 2017: 99). Dalam Budaya Lombok "Nyongkolan" ini terdapat nilai. Nilai-nilai yang mendidik atau nilai edukatif ini didapatkan anak melalui Pendidikan formal, nonformal, dan informal. Melalui program pendidikan tersebut anak-anak dapat mengembangkan nilai-nilai pendidikan. Publikasi pusat kurikulum (Samini, 2012: 9) menyatakan bahwa nilai pendidikan berfungsi (1) mengembangkan potensi dasar agar berhati baik, dan berperilaku baik, (2) memperkuat dan membangun perilaku bangsa yang multikultur, (3) meningkatkan peradaban bangsa yang kompetitif dalam pergaulan dunia. Nilai pendidikan ini bersumber dari agama, pancasila, budaya, dan tujuan pendidikan nasional, nilai-nilai tersebut antara lain bertanggungjawab, bersosialisasi,kekompakan, menjalin hububungan silaturrahmi dan nilai gotong royong.

Budaya adalah daya dari budi yang berupa cipta, karsa dan rasa, sedangkan kebudayaan adalah hasil dari cipta, karsa dan rasa tersebut. Secara prinsip kebudayaan itu adalah hasil usaha manusia, baik hasil berupa material maupun spiritual dan bahwa kebudayaan itu adalah milik dan warisan sosial, kebudayaan itu terbentuk dalam dan dengan interaksi sosial. Budaya dapat diukur berdasarkan karakteristik umum seperti yang dikemukakan oleh Robbins (1994) sebagai berikut: (1) Inisiatif individual, (2) toleransi terhadap tindakan beresiko, (3) arah, (4) integrasi, (5) dukungan dari manajemen, (6) kontrol, (7) identitas, (8) sistem imbalan, (9) toleranis terhadap konflik dan, (10) pola-pola komunikasi.

Tradisi nyongkolan diadakan selain untuk mengantar sepasang mempelai ke rumah keluarga mempelai wanita, juga dimaksudkan sebagai sarana pengumuman kepada masyarakat banyak bahwa pasangan yang diiringkan tersebut sudah resmi menikah, dan diharapkan juga bahwa tidak akan ada lagi orang yang mengganggu pasangan tersebut. Nyongkolan ini bisa dibilang merupakan puncak dari ritual bersatunya seorang terune (pemuda) dengan seorang dedare (gadis) dalam suatu ikatan perkawinan yang sah menurut agama dan adat. Prosesi nyongkolan tidak akan bisa dilepas dari suatu kegiatan yang disebut "Begawe" (hajatan) Jadi prosesi nyongkolan akan dikategorikan sebagai suatu hajatan atau Begawe. Begawe Nyongkolan akan dikemas dalam suatu pesta hajatan yang sangat meriah dan di sebut "Begawe Beleq" yang tidak sedikit mengeluarkan biaya.

Dalam acara Begawe Beleq baik pihak laki-laki dan perempuan masing-masing akan mempersiapkan segala sesuatu untuk prosesi acara nyongkolan tersebut. Maka disini letak kemeriahan dari acara tersebut, para tamu undangan akan di undang dua atau tiga hari sebelum hari $\mathrm{H}$ tersebut, untuk melakukan kegiatan memasakan nasi dan lauk pauk serta membuat jajanan pesta. Untuk menghibur para tamu yang bekerja biasanyanya pemilik hajatan (Epen Gawe) akan menyewa keseniankesenian tradisional khas Sasak seperti Gendang Beleq, Drama, Joget (sinden) dan sebagainya. Setelah puncak acara Tiba, pengantin laki-laki dan perempuan akan diiring atau di giring atau diarak layaknya Raja dan Permaisuri menuju kediaman keluarga pihak pengantin perempuan, pengiring ini akan mengenakan pakaian adat sasak layaknya prajurit dan dayang-dayang menghantar Raja dan Permaisuri sambil diiringi dengan musik tetabuhan tradisional baik berupa Gendang Beleq Atau kedodak. Sesampai dikediaman keluarga pengantin perempuan, pasangan pengantin akan melakukan sungkeman untuk meminta do'a restu kepada pihak keluarga juga sebagai tanda bahwa pihak keluarga sudah merestui untuk melepas anak gadis mereka dan dibawa oleh suaminya. 


\section{METODE}

\section{Rancangan Penelitian}

Metode penlitian yang digunakan untuk mencari penyelesaian permasalahan maka penelitian ini akan menggunakan metode penelitian kuantitatif deskriptif. Penelitian kualitatif merupakan suatu cara untuk mendapatkan atau mendekati persoalan secara etnografi, dalam penerapannya menekankan pada kelompok budaya dalam konteks natural selama periode tertentu, dengan tujuan mengetahuai budaya kelompok tersebut. Etnografi merupakan salah satu jenis penelitian kulitatif yang banyak berkaitan dengan antropologi. (Afifuddin dan Saebani, 2009:86).

\section{Lokasi Penelitian}

Sebelum melakukan penelitian, terlebih dahulu ditentukan obyek penelitian, sehinga mempermudah bagi peneliti untuk melakukan penelitian. Adapun tempat penelitian di desa Langko Kecamatan Janapria Kabupaten Lombok Tengah Tahun 2019. Alasan peneliti memilih lokasi ini adalah "karena Kabupaten Lombok Tengah merupakan daerah yang banyak melaksanakan tradisi kawin lari.

\section{Prosedur Penelitian}

Prosedur penelitian: membuat rumusan masalah, menentukan tujuan, dan manfaat penelitian, landasan teori, pengumpulkan data, analisis data (Social situation dan informant), reduksi data, penyajian data, dan memberikan kesimpulan. Sumber. Prosedur Penelitian (Sugiono, 2011:68).

\section{Instrumen Penelitian}

Instrumen dalam penelitian menurut Moleong (2003: 13) bahwa dalam instrumen penelitian kualitatif pengumpulan data lebih banyak bergantung pada dirinya sebagai alat pengumpul data. Adapun alat bantu yang bisa digunakan dalam penelitian kualitatif seperti alat kamera, dan dokementasi yang berhubungan dengan masalah penelitian, dan alat bantu lainnya. Tehnik penentuan informan dalam penelitian mengunakan Snowball
Sampling, Snowball Sampling merupakan tehnik penentuan sampel yang mula-mula jumlahnya kecil, kemudian membesar. Ibarat bola salju yang mengelinding yang lama-lama membesar.

\section{Metode Pengumpulan Data}

Metode pengumpulan data adalah caracara yang dapat digunakan oleh peneliti untuk mengumpulkan data (Arikunto, 2010). Adapun metode pengumpulan data yang digunakan dalam penelitia adalah; metode observasi, metode wawancara, dan metode dokumentasi.

\section{Jenis dan Sumber Data}

Secara teoritis jenis data dapat digolongkan menjadi dua kelompok, yaitu data kualitatif dan data kuantitatif. Sumber data yang digunakan sumber data primer dan sumber data sekunder.

\section{Teknik Analisis Data}

Analisis menurut Miles dan Huberman (2002:65) dibagi dalam tiga alur kegiatan yang terjadi secara bersamaan. Ketika alur tersebut adalah (1). Reduksi data, (2) Penyajian data, (3) penarikan simpulan.

\section{PEMBAHASAN}

\section{A. Nilai Edukatif}

Analisis nilai edukatif pada budaya "nyongkolan" ini dimulai dari analisis fakta kemanusiaan dan subjek kolektif. Menjabarkan pandangan dunia tentang budaya "nyongkolan". Indonesia adalah negara yang menghargai setiap masyarakat. Kesantunan adalah cerminan masyarakat Indonesia. Namun seiring berjalannya waktu nilai-nilai pendidikan semakin diabaikan, banyak terjadi penindasan, kekerasan, tindakan sewenangwenang yang menyebar ke segala pelosok negeri dan berbagai kalangan, baik kalangan pejabat, masyarakat biasa, maupun pelajar. Nilai-nilai pendidikan perlu ditingkatkan.

Permasalahan-permasalahan tentang konflik dalam keluarga, sekolah, dan masyarakat dalam budaya "nyongkolan" ini menimbulkan ketegangan (tention). Nilainilai pendidikan dalam budaya "nyongkolan" 
Pembahasan tentang nilai-nilai edukatif yang terkandung dalam budaya "nyongkolan" dapat dilihat dalam analisis berikut ini.

a. Pendidikan

Sekolah sebagai lembaga pendidikan formal menjadi panutan dalam berbagai hal termasuk pendidikan karakter. Pendidikan karakter di sekolah disesuaikan dengan tingkat usia perkembangan mental peserta didik. Pendidikan merupakan sebuah proses yang membantu menumbuhkan, mengembangkan, mendewasakan, membuat yang tidak tertata menjadi semakin tertata, semacam proses penciptaan sebuah kultur dan tata keteraturan dalam diri maupun dalam diri orang lain (Sutiyono, 2013: 314). Pendidikan pada hakekatnya adalah proses penyempurnaan diri manusia terus menerus yang berlangsung dari generasi yang satu ke generasi yang lain (Koesoema A, 2011). Pendidikan mempunyai peranan yang sangat penting dalam menyiapkan sumber daya yang berkarakter dan berkualitas. Pendidikan karakter dapat dimaknai sebagai pendidikan nilai, pendidikan budi pekerti, pendidikan moral, pendidikan watak yang bertujuan mengembangkan kemampuan siswa untuk memberikan dengan sepenuh hati keputusan baik-buruk, memelihara apa yang baik, dan mewujudkan kebaikan itu dalam kehidupan sehari-hari (RAN Kemendiknas 2010-2014). Pendidikan nilai adalah pendidikan seumur hidup dan pendidikan nilai merupakan pembentukan karakter anak didik (Borong, 2007).

b. Tanggung jawab

Tangung jawab adalah tugas yang harus dilakukan dengan sungguh sungguh dan tulus. Saat ini nilai tanggung jawab mulai menghilang misalnya anak yang harus berbaktikepada orang tua malah sebaliknya, durhaka pada orang tua. Manusia juga sering lupa tentang tanggung jawabnya kepada Tuhan yang telah menciptakan, mereka lebih mementingkan duniawi dan mengabaikan kepentingan rohani. Penggambaran nilai tanggung jawab dapat dilihat pada kutipan

\section{c. Sosialisai}

Sosialisasi adalah proses pnanaman atau mentransfer kebiasaan atau nilai dan aturan dari satu generasi ke generasi lainnya dalam sebuah kelompok atau masyarakat. Sejumlah sosiolog menyebut sosialisasi sebagai teori mengenai peranan Karena dalam proses sosialisasi diajarkan peranperan yang harus dijalankan oleh individu.

d. Kompak

Kompak adalah bersatu padu (dalam menanggapi atau menghadapi suatu perkara Definisi dan arti kata kekompakan di KBBI adalah perihal kompak. Kekompakan berasal dari kata dasar kompak. Kekompakan memiliki arti dalam kelas nominal atau kata benda sehingga kekompakan dapat menyatakan nama dari seseorang, tempat, atau semua benda dan segala yang dibendakan.

e. Silaturrahmi

Menurut kamus besar bahasa indonesia, silaturrahmi merupakan tali persaudaraan atau persahabatan.

f. Gotong royong

Karakter yang terdapat dalam tradisi nyongkolan adalah semangat gotong royong dan tolong-menolong untuk kepentingan pribadi maupun kepentingan umum. Membangun rasa peduli terhadap sesama dan tentu untuk menjaga keutuhan bangsa dan negara. Sebab itu, pemuda dan anak-anak sekolah sebgai gnerasi bangsa selanjutnya sebagai titik tengah yang berada antara kaum tua dan kaum muda berperan penting untuk belajar mempertahankan dan belajar memberikan contoh yang baik kepada generasi selanjutnya

Semangat gotong royong dan tolongmenolong adalah inti dari kebersamaan dalam hidup bermasyarakat. Kepedulian terhadap sesama merupakan karakter penting dalam hidup dalam lingkungan yang sama. Hal yang diharapkan tentu mempunyai pengaruh positif terhadap segala tindakan. Mangunhardjana (1986: 29) bahwa: Pemuda mampu menciptakan dan membina kebersamaan dan kerja sama 
dengan orang lain sebagai tempat untuk mengembangkan diri dan mencapai tugas pekerjaan bersama, dalam semangat setia kawan dan Bhinneka Tunggal Ika.

\section{B. Budaya}

Bahasa indonesia mengartikan kebudayaan dari bahasa Sanksekerta "buddhayah" (Ahmadi; 2004:56). Yaitu bentuk jamak dari buddhi yang berarti budi atau akal. Pendapat lain mengatakan, bahwa kata budaya adalah sebagai suatu perkembangan dari kata majemuk : budi daya, yang berarti daya dari budi. Karena itu mereka membedakan antara budaya dan kebudayaan. Budaya adalah daya dari budi yang berupa cipta, karsa dan rasa, sedangkan kebudayaan adalah hasil dari cipta, karsa dan rasa tersebut. Secara prinsipil kebudayaan itu adalah hasil usaha manusia, baik hasil berupa material maupun spiritual dan bahwa kebudayaan itu adalah milik dan warisan sosial, kebudayaan itu terbentuk dalam dan dengan interaksi social (Sutiyono, 2011: 46).

Budaya dapat diukur berdasarkan karakteristik umum seperti yang dikemukakan oleh Robbins(1994) sebagaiberikut:(1) Inisiatif individual, (2) toleransi terhadap tindakan beresiko, (3) arah, (4) integrasi, (5) dukungan dari manajemen, (6) kontrol, (7) identitas, (8) sistem imbalan, (9) toleranis terhadap konflik dan, (10) pola-pola komunikasi.

Budaya menurut Soekamto berasal dari kata Sansekerta "budayyah" yang merupakan bentuk jamak "budhi" yang berarti akal. Dengan demikian budaya dapat di artikan sebagai hal-hal yang berhubungan dengan akal dan budi (Soekanto; 1983:166).

A.L. Kroeber dan C. Kluckhohn dalam bukunya Culture, a Critical Review of Concepts and Definitions (1952) mengatakan bahwa kebudayaan adalah manifestasi atau penjelmaan kerja jiwa manusia dalam arti seluas-luasnya. Culture unsur dari kebudayaan terbagi dalam 7 unsur yaitu :

1. Religi dan upacara keagamaan

2. Sistem organisasi kemasyarakatan

3. Sistem pengetahuan

4. Sistem mata pencaharian hidup
5. Sistem teknologi dan peralatan

6. Bahasa

7. Kesenian

\section{Nyongkolan}

Nyongkolan adalah berasal dari kata songkol atau sondol yang berarti mendorong dari belakang. secara kasar berarti menggiring (mengiring -pen) dalam bahasa sasak dialek Petung Bayan. Nyongkolan adalah prosesi adat yang dijalankan apabila adanya proses pernikahan antara Laki-Laki (Terune) dan Perempuan (Dedare) di dalam suku Sasak. Biasanya nyongkolan akan dilaksanakan setelah proses akad nikah, untuk waktu bisa ditentukan oleh kedua belah pihak. Ada yang meringkas dalam satu waktu ada pula yang akan melakukan nyongkolan seminggu setelah proses akad nikah dilaksanakan. Upacara nyongkolan biasanya diikuti oleh banyak orang, dan pasangan pengantin yang diarak diperlakukan seperti seorang raja dan ratu yang berjalan diiringkan oleh para pengawal, prajurit dan dayang-dayangnya. Oleh karena itulah pengantin sering pula disebut raja sejelo yang artinya raja sehari. Ada kebiasaan yang berlaku dalam masyarakat, yaitu bahwa jika seseorang menolak untuk ikut sebagai pengiring dalam acara nyongkolan, maka jika suatu saat orang tersebut mengadakan acara nyongkolan, akan banyak pula orang yang akan menolak untuk mengiringinya. Jadi, dengan melihat dari panjangnya barisan, bisalah diketahui apakah sang mempelai termasuk orang yang mudah bersosialisasi atau bukan.

Pada hakikatnya tradisi nyongkolan dihajatkan untuk menjalankan ruh agama itu sendiri karena dalam kegiatan nyongkolan ada unsur syiar untuk memperkenalkan kedua mempelai kepada kaum kerabat dan para tamu yang hadir, dan dalam kesempatan ini juga kedua mempelai dibawa menemui kedua orang tuanya, sebagai simbul untuk memohon maaf atas perbuatannya yang telah meninggalkan rumahnya untuk kawin. Tetapi perlu diingat dalam pelaksanaan nyongkolan tersebut dilakukan dengan tertib dan teratur dengan tidak melanggar norma adat dan agama. Inilah 
hakikat nyongkolan yang dihajatkan oleh tokoh adat, tokoh agama, pemerintah dan masyarakat sasak yang cinta akan budayanya. berikut:

Adapun proses nyongkolan sebagai

\section{a. Ngiring}

Ngiring adalah berjalan dari kediaman keluarga pengantin pria menuju kediaman keluarga pengantin wanita dengan diiiring oleh keluarga dan juga masyarakat setempat yang biasanya juga diikuti oleh tokoh masyarakat, pemuka agama dan juga pemuka adat setempat. Orang-orang yang melakukan nyongkolan ini semuanya mengenakan pakaian adat lengkap, dimana yang pria juga akan membekal keris atau golok yang diselipkan di pinggang ataupun disandang di punggungnya, sementara yang wanita mengenakan kebaya khas Suku Sasak lengkap dengan semua aksesorisnya.

Upacara nyongkolan biasanya diikuti oleh banyak orang, dan pasangan pengantin yang diarak diperlakukan seperti seorang raja dan ratu yang berjalan diiringkan oleh para pengawal, prajurit dan dayang-dayangnya. Oleh karena itulah pengantin sering pula disebut raja sejelo yang artinya raja sehari. Ada kebiasaan yang berlaku dalam masyarakat, yaitu bahwa jika seseorang menolak untuk ikut sebagai pengiring dalam acara nyongkolan, maka jika suatu saat orang tersebut mengadakan acara nyongkolan, akan banyak pula orang yang akan menolak untuk mengiringinya. Jadi, dengan melihat dari panjangnya barisan, bisalah diketahui apakah sang mempelai termasuk orang yang mudah bersosialisasi atau bukan.

Tradisi nyongkolan diadakan selain untuk mengantar sepasang mempelai ke rumah keluarga mempelai wanita, juga dimaksudkan sebagai sarana pengumuman kepada masyarakat banyak bahwa pasangan yang diiringkan tersebut sudah resmi menikah, dan diharapkan juga bahwa tidak akan ada lagi orang yang mengganggu pasangan tersebut.

\section{b. Baju adat}

1. Baju adat laki

Dalam pakaian adat laki-laki suku Sasak terdapat 6 perlengkapan yang menjadi pelengkap sehingga menjadi sebuah pakaian adat, di antaranya sebagai berikut :

- Sapuk

Sapuk merupakan mahkota yang digunakan sebagai lambang penghormatan kepada Tuhan Yang Maha Esa, serta menjaga pemikiran pemakainnya dari hal-hal kotor dan tidak baik. Ketika acara adat biasanya pria memakai sapuk jadi atau parade yang terbuat dari bahan songket benang emas.

- Baju

Baju pegon merupakan pakaian adat suku sasak yang mendapat pengaruh dari suku jawa dengan mengadopsi model jas eropa, baju pegon memiliki lambang keanggunan dan kesopanan. Kain yang digunakan untuk membuat baju pegon umumnya berwarna gelap dan tidak bermotif.

- Leang atau dodot

Dodot merupakan kain songket yang berfungsi untuk menyelipkan keris. Beragam motif kain songket yang digunakan untuk dodot diantaranya subahnale, keker, dan bintang empet yang bermakna semangat dalam berkarya dan pengabdian kepada masyarakat.

- Kain dalem

Kain dalam dengan Wiron merupakan jenis kain yang digunakan sebagai penutup tubuh bagian bawah yang meliputi pusar sampai mata kaki dengan ujung kain lurus kebawah sebagai lambang tawadhu (rendah hati). Kain yang digunakan biasanya berasal dari bahan batik jawa dengan motif tulang nangka atau kain pelung hitam, dapat juga menggunakan motif tapo kemalo dan songket dengan motif serat penginang. Dalam penggunaan kain wiron tidak diperkenankan menggunakan kain polos berwarna putih atau merah.

- Kris

Penggunaan keris sebagai pelengkap pakaian adat yang melambangkan kesatriaan dan keberaniaan dalam mempertahankan martabat pemakainya. Dalam atauranya penggunaan keris sebagai lambang adat bagian mukanya harus menghadap kedepan, jika terbalik 
maka bermakna berperang atau siaga. Pada perkembangannya penggunaan keris dapat diganti dengan pisau raut atau pemaja.

- Slendang umbak

Selendang Umbak merupakan sabuk yang khusus diperuntukkan bagi para pemangku adat atau pengayom masyarakat yang dibuat dengan ritual khusus dalam keluarga sasak. Jenis kain yang digunakan umumnya berwarna merah dan hitam dengan panjang berkisar empat meter yang dihiasi dengan kepeng bolong. Seledang umbak sebagai lambang kasih sayang dan kebijakan bagi pemakainya.

Dalam pakaian adat wanita suku Sasak terdapat 6 perlengkapan yang menjadi pelengkap sehingga menjadi sebuah pakaian adat, diantaranya sebagai berikut :

- Pangkang

Pangkak merupakan mahkota emas berbentuk bunga cempaka dan bunga mawar yang diselipkan disela-sela konde atau sanggul.

- Tangkong

Tangkong merupakan lambang keanggunan, jenis pakaian ini umumnya dibuat dari bahan beludru atau brokat dan dapat berupa pakaian kebaya dari bahan berwarna cerah atau gelap.

- Tongkak

Tongkak merupakan kain sabuk panjang dengan bagian ujung berumbai yang dililitkan pada bagian pingang sebelah kiri dan digunakan sebagai lambang kesuburan dan pengabdian.

- Lempot

Lempot merupakan kain tenun panjang bercorak khas yang disampirkan pada pundak bagian kiri. Penggunaan selendang ini memiliki makna sebagai perlambang kasih sayang.

- Kereng

Kereng meruapakan kain tenun songket (kain kereng) sebagai lambang kesopanan dan kesuburan yaitu dililitkan dibagian pingang sampai sebatas mata kaki.

- Asesoris
Ditambah pula penggunaan endit atau pending yaitu berupa rantai perak yang difungsikan sebagai ikat pinggang, onggaronggar atau hiasan berupa bunga emas yang diselipkan dibagian konde, giwang atau anting-anting, serta suku atau ketip yang terbuat dari uang emas dan perak yang dibentuk bros, serta kalung.

\section{c. Gendang beleq}

Gendang Beleq adalah nama sebuah instrumen musik, yaitu gendang berukuran panjang lebih dari satu meter yang disandang pada pundak pemain Kata Beleq dalam bahasa Sasak berarti Besar. Tari Gendang Beleq merupakan tari perang walaupun tidak ada gerak yang menunjukkan perkelahian dan tidak ada pula yang membawa senjata perang, karena garapan geraknya selalu menunjukkan watak maskulin/ sikap jantan. Tari Gendang Beleq dahulu berfungsi sebagai tari pengiring para ksatria yang akan maju ke medan perang atau menyambut para pahlawan yang pulang dari medan perang.

Satu ciri khas dari Tari Gendang Beleq ialah bahwa yang menari adalah pemainpemain musik itu sendiri. Karena sifatnya yang atraktif, Saat ini, Gendang Beleq ini sering kali diadakan untuk mengiringi arak-arakan pengantin (atau yang biasa disebut Upacara Nyongkolan) atau arak-arakan anak yang akan dikhitan, dan untuk penyambutan tamu penting di Bandara International Lombok.

Gendang Beleq dimainkan secara berkelompok. Gendang Beleq terdiri dari dua kelompok Gendang Beleq yang disebut mame (laki-laki) dan gendang nine (perempuan) yang berfungsi sebagai pembawa dinamika. Juga terdiri atas sebuah Gendang Kodeq (gendang kecil), perembak belek dan perembak kodeq sebagai alat ritmis, gong dan dua buah reog, yakni reog nina dan reog mama sebagai pembawa melodi Para pemain memainkan Gendang Beleq dengan cara sambil menari. Pemain nya berkisar antara $13 \mathrm{~s} / \mathrm{d} 17$ orang.

Gendang Beleq memiliki nilai filosofis yang terkandung didalamnya. Masyarakat Lombok menilai bahwa Gendang Beleq ini 
memiliki keindahan, kesabaran, kebijakan dan kepahlawanan yang diharapkan dapat menyatu dengan masyarakat Sasak khususnya. Tari ini juga di pertontonkan di sebuah desa agar dapat menarik para wisatawan yang mengambil paket tour lombok dan yang menjelajahi Pulau Lombok.

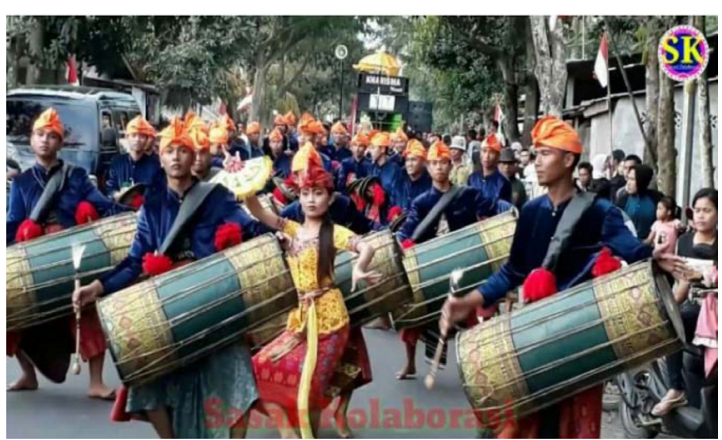

Gambar 1. Penampilan Kendang Beleg dalam acara Nyongkolan di Lombok, Nusa Tenggara Barat.

\section{KESIMPULAN}

Berdasarkan hasil penelitian mengenai Nilai Edukatif Pada tradisi budaya nyongkolan Lombok untuk di jadikan Sebagai Bahan Ajar di SMA Kelas XII dapat disimpulkan dari analisis tradisi budaya nyongkolan Lombok.

Budaya nyongkolan juga harus di apresiasi oleh masyarakat lombok karen banyak terdapat nilai edukatif pada budaya tersebut untuk di jadikan bahan ajar ke anak sekolah atau di dunia pendidikan untuk menjaga kelestarian budaya tersebut agar budaya peninggalan nenek moyang kita tradisi terdahulu tidak punah begitu saja, adapun cara mengantisipasi nya dengan cara memperkenalkan budaya nyongkolan sebagai bahan ajar di sekolah lebih cendrung untuk mengkaji nilai edukatif yang terkadung pada budaya nyongkolan tersebut, adapun nilai edukatif yang bisa di peroleh dalam budaya nyongkolan bertanggung jawab, bersosialisasi, kekompakan, kebersamaan, menjalin hububungan silaturrahmi dan nilai gotong royong.

Latar tempat (Kabupaten Lombok Tengah Kecamatan Janapria Desa Langko) latar sosial kesederhanaan, pendidikan, kearifan penduduk, kedamaian. Sudut pandang yang digunakan adalah sudut pandang pemangku adat dan masyarakat stempat. Nilai Edukatif yang yang bisa di peroleh dalam budaya nyongkolan bertanggung jawab, bersosialisasi, kekompakan, kebersamaan, menjalin hububungan silaturrahmi dan nilai gotong royong. Hasil penelitian tradisi budaya nyongkolan adat sasak lombok ini dapat di jadikan sebagai bahan ajar di SMA kelas XII.

\section{DAFTAR PUSTAKA}

Ahmadi, Abu. 2004. Sosiologi Pendidikan. Jakarta : PT. Asdi Mahasatya.

Borrong, R.P. 2007. Pentingnya Pendidikan Dalam Membangun Kehidupan Bangsa. KRITIS, Jurnal Studi Pembangunan Interdisipliner, XIX (2).

KoesoemaA, Doni. 2011.Pendidikan Karakter: Strategi Mendidik Anak di Zaman Global. Jakarta: PT Gramedia.

Mangunhardjana, A. M. 1989. Pendampingan Kaum Muda. Yogyakarta.

Noviyanti, Siti Risa., Sutiyono, S. 2017. Bentuk, Perubahan Fungsi, dan Nilai-nilai Edukatif pada Musik Tari Japin Tahlul di Amuntai. Imaji: Jurnal Seni dan Pendidikan Seni, 15(1), 97-112.

Suardana I Wayan. 2009. Pengembangan Metode Analisis Bentuk Dalam Pengajaran Seni Lukis Di Jurusan Pendidikan Seni Rupa Fbs Uny. Imaji: Jurnal Seni dan Pendidikan Seni.

Soekamto, Soerjono. Sosiologi Suatu Pengantar. Jakarta: Rajawali 1983.

Sugiyono.2011. Metode Penelitian Kuantitatif, Kualitatif dan R \& D. Bandung:Alfabeta.

Sutiyono. 2011. Tradisi Masyarakat sebagai Kekuatan Sinkretisme di Trucuk, Klaten. Jurnal Penelitian Humaniora, Vol. 16, No.1, 45-59.

Sutiyono, S. 2013. Penerapan Pendidikan Budi Pekerti sebagai Pembentukan Karakter Siswa di Sekolah Jurnal Pendidikan Karakter, Tahun III, Nomor 3, 309-320. 